\title{
The Relationships between Two Different Drinking Water Fluoride Levels, Dental Fluorosis and Bone Mineral Density of Children
}

\author{
S.R. Grobler*, A.J. Louw, U.M.E. Chikte, R.J. Rossouw and T.J. van W. Kotze
}

Oral and Dental Research Institute, Faculty of Dentistry, University of the Western, Cape, Republic of South Africa

\begin{abstract}
This field study included the whole population of children aged 10-15 years (77 from a $0.19 \mathrm{mg} / \mathrm{L} \mathrm{F}$ area; 89 from a $3.00 \mathrm{mg} / \mathrm{L} \mathrm{F}$ area), with similar nutritional, dietary habits and similar ethnic and socioeconomic status. The fluoride concentration in the drinking water, the bone mineral content, the bone density and the degree of dental fluorosis were determined. The left radius was measured for bone width, bone mineral content, and bone mineral density. The mean fluorosis score was 1.3 in the low fluoride area and 3,6 in the high fluoride area. More than half the children in the low fluoride area had no fluorosis (scores 0 and 1) while only $5 \%$ in the high fluoride area had none. Severe fluorosis (30\%) was only observed in the high fluoride area. The Wilcoxon Rank Sum Test indicated that fluorosis levels differed significantly $(\mathrm{p}<0.05)$ between the two areas. No relationships were found between dental fluorosis and bone width or between fluorosis and bone mineral density in the two areas (Spearment Rank correlations). A significant increase in bone width was found with age but no differences amongst and boys and girls. A significant positive correlation was found in the high fluoride area between bone mineral density over age. In the 12-13 and 13-14 year age groups in the high fluoride area, girls had higher bone mineral densities. However, a significant negative correlation $(\mathrm{p}<0.02)$ was found for the low fluoride area $(0.19 \mathrm{mg} / \mathrm{L} \mathrm{F})$ over age.
\end{abstract}

\section{INTRODUCTION}

Today it is believed that fluoridated water (whether naturally or artificially fluoridated) can be generally regarded as a safe, simple and cost-effective public health measure to prevent dental caries and has its greatest influence on socially disadvantaged children who have the most tooth decay [1-6]. However, a too high drinking water fluoride concentration will lead to unesthetical dental fluorosis and the development of skeletal fluorosis. In general, dental fluorosis increased with increasing drinking water fluoride concentrations [7-12]. In 2005, the American Dietetic Association (ADA) [13] reaffirmed the importance of appropriate fluoride as an important element for all mineralized tissues in the human body. They stated that topical and systemic fluorides have resulted in major reductions in dental caries, while water fluoridation is considered as one of the most beneficial public health measures throughout the life span.

Bone strength is primarily determined by bone mineral density (BMD), but bone quality (e.g. bone remodeling, structural and material properties) is also an important determinant of bone strength. It was also suggested that optimal drinking water fluoridation $(1 \mathrm{mg} / \mathrm{L})$, did not influence peak bone density [14].

A summary of 33 studies since 1991 was done by the National Health and MRC (medical research council) of Australia [15] on the effects of fluoride on bone. One of two cohort studies showed an increase in fracture incidence at fluoride levels four times greater than optimal water fluoridation and the other showed no effect after 20 years' optimal

*Address correspondence to this author at the Oral and Dental Research Institute, Faculty of Dentistry, University of the Western, Cape, Republic of South Africa; Tel: 27-21-9373023; Fax: 27-21-937 3025;

E-mails: srgrobler@uwc.ac.za and srg1@mweb.co.za fluoridation. The results of ecological studies were found to be conflicting but the clinical trials predominantly showed increased bone density with fluoride treatments of 9-23 mg F per day for 4 years. A low risk of hip fracture for people ingesting drinking water containing $1 \mathrm{mg} / \mathrm{L} \mathrm{F}$ was also reported [9]. From the above studies it was concluded [8] that fluoride up to $1 \mathrm{mg} / \mathrm{L}$ does not have an adverse effect on bone strength, bone mineral density or incidence of fracture. A report by the National Research Council [16] concluded that the EPA's (environmental protection agency) maximum drinking water fluoride standard $(4 \mathrm{mg} / \mathrm{L})$ is too high and does not protect against adverse health effects such as skeletal fluorosis especially for life-long residents in these areas. However, the level for aesthetic or cosmetic effects such as dental fluorosis was set lower at $2 \mathrm{mg} / \mathrm{L}$ fluoride [16].

In a low fluoride area with a high dental fluorosis index of 3.7 which was attributed to high fluoride containing bricktea, skeletal abnormalities in the wrist were associated with the early-stage of skeletal fluorosis [17]. The question then arises whether low drinking water fluoride concentrations which were normally associated with lower degrees of dental fluorosis have any effect on bone density and whether different degrees of fluorosis scores can be used as a possible indication of bone density and possible warning signs for skeletal fluorosis.

Therefore, the purpose of this study was to determine relationships amongst two different drinking water fluoride levels, dental fluorosis and bone mineral density of children.

\section{MATERIALS AND METHODOLOGY}

The study included all available children aged 10-15 yrs, with similar nutritional and dietary habits and similar ethnic and socio-economic status, from a low fluoride area $(0.19$ 
$\mathrm{mg} / \mathrm{L} \mathrm{F})$ and a high fluoride area $(3.00 \mathrm{mg} / \mathrm{L} \mathrm{F})$. Both areas are located in arid rural sections of South Africa and during this study they were dependent on boreholes for their drinking water. The number of children investigated were 77 (boys $=42$ ) from the low $F$ area and 89 (boys $=42$ ) from the high $\mathrm{F}$ area. Every effort was made to ensure that the children had been born and raised in the areas. The children were examined for dental fluorosis using Dean's criteria according to the World Health Organization guidelines [18]. Water fluoride levels were determined potentiometrically, according to the method described by Nicholson and Duff [19] and were analyzed over a period of approximately 10 years $[20,21]$.

The examiner was standardized and calibrated for examiner variability, using an expert (gold standard) prior to and during examinations [22]. Examiner agreement (inter- and intra-) was determined using the weighted kappa, which takes into account the relative impact of each possible disagreement. Linear weights, which are proportional to the deviation of individual ratings, were used [23]. The intraand inter-examiner agreement scores for the fluorosis index $(\mathrm{k}=0.78$ and 0.70 , respectively) were substantial according to the scale of Landis and Koch, thus meeting the scientific requirement for validity and reliability [24]. Agreement was also monitored throughout the study by re-examining $10 \%$ of the sample, with the result being of the same order as the pre-survey finding.

The Norland single energy $\left({ }^{125} \mathrm{I}\right)$ photon absorptiometer (Model 278A) was used for the bone measurements [25, 26]. The left radius was measured for bone width and bone mineral content. The exact point of measurement of the radial bone mass was determined by measuring the distances between the proximal end of the olecranon and the distal tip of the ulna styloid, dividing the measurement distance by 3 and then positioning the support plate so that the beam passed through the point at this $1 / 3$ distance from the ulna styloid. The arm was secured with straps and the subjects cautioned not to move during the readings. The bone width (BW) and bone mineral content (BMC) values were measured (at this site it is mainly cortical bone) and the bone mineral density
(BMD) (normalised for bone width) calculated. Three readings were taken from each subject and the mean values were recorded in the data basis.

To accommodate concerns regarding the difference in onset of adolescence the genders were separated into three age groups, which resulted in three age groups and six gender groups.

\section{RESULTS}

Since analysis of the data (Mann-Whitney U test) showed no significant difference in the fluorosis scores between girls and boys, the results for the these two series were combined in the fluorosis data. The prevalence (Table 1) of fluorosis (scores 2-5) was $49 \%$ in the low fluoride area and $96 \%$ in the high fluoride area. There was $38 \%$ children in the low fluoride area with no fluorosis (Table $\mathbf{1}$ ) in contrast to only $1 \%$ in the high fluoride area. No children in the low F area had severe fluorosis in comparison to $30 \%$ in the high $\mathrm{F}$ area. The mean fluorosis score (1.3) was significantly lower (Wilcoxon Rank Sum Test) in the low F area than in the high $\mathrm{F}$ area (3.6).

Table 2 summarizes the mean values (standard deviation in brackets) over age for bone width, bone mineral content and bone mineral density for the two different areas.

Fig. (1) shows the bone width (BW); (Fig. 2) the bone mineral content (BMC) and (Fig. 3) the bone mineral density (BMD) for boys and girls over the 3 age groups for the low $(0.19 \mathrm{mg} / \mathrm{L} \mathrm{F})$ and high fluoride $(3.00 \mathrm{mg} / \mathrm{L} \mathrm{F})$ areas. The values encircled were found to be not statistically significantly different within a particular age group ( $\mathrm{p}>0.05$; Tukey-Kramer Multiple-Comparison Test).

No relationship was found between dental fluorosis and bone density in any of the two areas (Spearman Rank correlation). However, statistical significant differences $(p<0.05)$ were found in the fluorosis levels between the two different areas (Wilcoxon Rank Sum Test).

In general boys had wider bone than girls (Fig. 1). However, there was no significant difference in bone width

Table 1. Dental Fluorosis Score by Fluoride Area

\begin{tabular}{|c|c|c|c|c|}
\hline Dental Fluorosis Score & \multicolumn{2}{|c|}{$\begin{array}{c}\text { Low F Area } \\
(\mathrm{F}=0.19 \mathrm{mg} / \mathrm{L})\end{array}$} & \multicolumn{2}{|c|}{$\begin{array}{c}\text { High F Area } \\
(F=3.0 \mathrm{mg} / \mathrm{L})\end{array}$} \\
\hline $0=$ normal & 29 & 37.6 & 1 & 1.1 \\
\hline $1=$ questionable & 11 & 14.3 & 3 & 3.4 \\
\hline $3=$ mild & 14 & 18.2 & 16 & 18.0 \\
\hline $4=$ moderate & 4 & 5.2 & 29 & 32.6 \\
\hline $5=$ severe & 0 & 0.0 & 27 & 30.3 \\
\hline
\end{tabular}

* standard deviation. 
Table 2. The Mean Values for Age (Years), Bone width (cm), Bone Mineral Content $(\mathrm{g} / \mathrm{cm})$ and Bone Mineral Density $\left(\mathrm{g} / \mathrm{cm}^{2}\right)$ for the Two Different Areas

\begin{tabular}{|c|c|c|c|}
\hline Age Groups & $10 \& 11$ & $12 \& 13$ & $14 \& 15$ \\
\hline \multicolumn{4}{|c|}{ Average Bone Width (cm) } \\
\hline Sample number (n) & 23 & 13 & 11 \\
\hline High $F$ area boys & 0.98 & 1.08 & 1.14 \\
\hline Low $\mathrm{F}$ area girls & 0.98 & 1.04 & 1.18 \\
\hline Sample number (n) & 14 & 18 & 3 \\
\hline Low $\mathrm{F}$ area boys & 1.01 & 1.15 & 1.21 \\
\hline High $F$ area girls & 1.29 & 1.56 & 1.80 \\
\hline High $F$ area boys & 1.29 & 1.41 & 1.80 \\
\hline Low $\mathrm{F}$ area girls & 1.26 & 1.33 & 1.18 \\
\hline Low $\mathrm{F}$ area boys & 1.32 & 1.29 & 1.52 \\
\hline \multicolumn{4}{|c|}{ Average Bone Mineral Density $\left(\mathrm{g} / \mathrm{cm}^{2}\right)$} \\
\hline Age groups & $10 \& 11$ & $12 \& 13$ & $14 \& 15$ \\
\hline High $\mathrm{F}$ area girls & 1.34 & 1.51 & 1.63 \\
\hline
\end{tabular}

within boys or girls or between boys and girls in any of the age groups (6 groups; Fig. 1). A strong positive linear relationship was detected between age and BW within each of the genders and two fluoride groups $(\mathrm{p}<0.05$; Spearman rank correlation).

The BMC increased with age in the high fluoride area for boys and girls but varied in the low fluoride area. Significant differences in the BMC in the 14-15 year age group and 1213 year age group (Fig. 2) was found amongst boys from the high fluoride area $(3 \mathrm{mg} / \mathrm{L})$ and girls from the low fluoride area but no differences in the 10-11 year age group.

In general, the BMD (Fig. 3) increased with age in the high fluoride area but decreased significantly with age in the low fluoride area. ( $\mathrm{p}<0.05$; Spearman Rank Correlation Test). In a comparison between the two different fluoride areas for the bone mineral density at a specific age group, differences were found (Fig. 3; p $<0.05$; Tukey Kramer Multiple Comparison test). In the 10-11 year age group no significant differences were found, while in the 12-13 year age group there was a significant difference between girls from the high fluoride area and boys from the low fluoride area. In the 14-15 year age group the BMD of boys and girls in the high fluoride area differed significantly from the boys and girls in the low fluoride group.

\section{DISCUSSION AND CONCLUSION}

This study was conducted in two groups of children who lived continuously since birth in separate areas, each of which had constant levels of fluoride in the drinking water. In most cases, not only had the children lived in a specific area since birth but so had their parents. The children in the two fluoride areas were of mixed ethnicity, originating from Khoi, Caucasian, and Negroid roots that developed into a homogenous ethnic group over many years. The children were also from the same low socio-economic group, as identified according to the mean values of the residential properties and/or units status as described and used by Du Plessis [6] for South Africa. The staple diet throughout consisted mainly of bread and potatoes with sporadic intake of other vegetables and meat. Personal communication with primary health care personnel did not reveal the prevalence of obvious under-nutrition, nor could any dietary habits be detected that might have contributed significantly to the ingestion of fluoride. These children had virtually no dental care or fluo- 


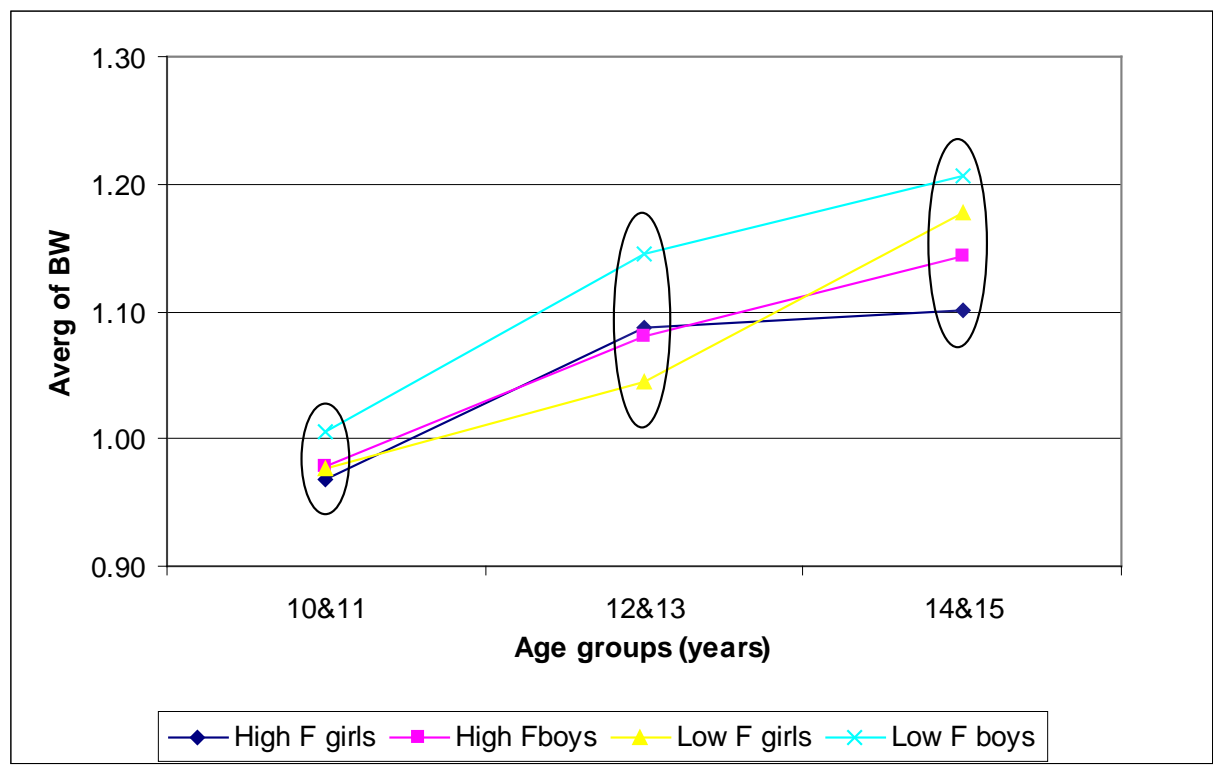

Fig. (1). The mean values of the bone width (BW) over years for the low $\mathrm{F}$ areas $(0.19 \mathrm{mg} / \mathrm{L} \mathrm{F})$ and high $\mathrm{F}$ area $(3.00 \mathrm{mg} / \mathrm{L} \mathrm{F})$. The values encircled (within each age group) were not significantly different ( $\mathrm{p}>0.05$; Tukey Kramer).

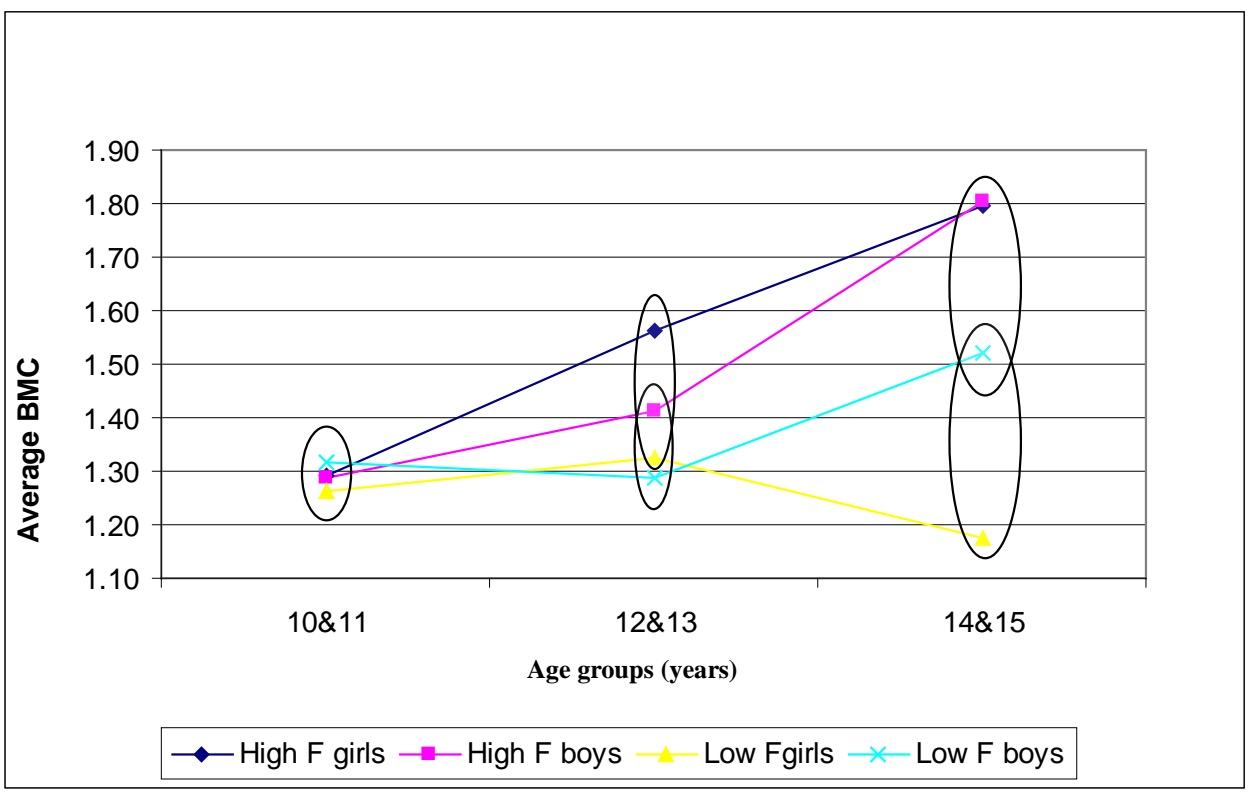

Fig. (2). The mean values of the bone mineral content (BMC) over years for the low $\mathrm{F}$ area $(0.19 \mathrm{mg} F / \mathrm{L})$ and high $\mathrm{F}$ area $(3.00 \mathrm{mg} F / \mathrm{L})$. The values encircled (within each age group) were not significantly different ( $p>0.05$; Tukey Kramer).

ride therapy, including the use of fluoride-containing toothpaste, prior to this study. Furthermore, the drinking water sources (bore holes) did not change over the life-span of the children, which is an advantage that should be appreciated. Thus, only small insignificant seasonal variations [27] in the drinking water fluoride levels could have occurred. The average maximum daily temperature for the two areas was also high $\left(\sim 25^{\circ} \mathrm{C}\right)$ and the rainfall very low. Therefore, one would expect elevated water consumption [28].

In areas in Nigeria [29] where the water F levels varied between 0.05 and $0.4 \mathrm{mg} / \mathrm{L}$ it was stated that $49 \%$ had no fluorosis and $42 \%$ very mild which is about similar to our findings (Table 1) in the low $\mathrm{F}$ area $(\mathrm{F}=0.19 \mathrm{mg} / \mathrm{L})$. Also quite similar to our findings, a fluorosis index of 1.3 was reported for a low $F$ area $(F=0.25 \mathrm{mg} / \mathrm{L})$ in the Sudan [11] but a value of 2.1 was reported for an area with $2.5 \mathrm{mg} / \mathrm{L} \mathrm{F}$ in the water in comparison to 3.6 in our $3.0 \mathrm{mg} / \mathrm{L} \mathrm{F}$ area. In an area $(\mathrm{F}=2.15 \mathrm{mg} / \mathrm{L})$ in Kenia [12] dental fluorosis was found to be $100 \%$ with $50 \%$ of the children with severe fluorosis (score 5), which is worse than in our high $\mathrm{F}$ area (30\%; Table 1). A very high fluorosis value (4.5) was also reported in South Africa [8] for a drinking water F level of $3.7 \mathrm{mg} / \mathrm{L}$ for life-long resident children. In a survey conducted in two high-fluoride areas (3.5 and $12.5 \mathrm{mg} / \mathrm{L}$ ) in Ethiopia [30], it was found that all children born there had fluorosis. However, in a low drinking water $\mathrm{F}$ area a dental fluorosis score of $84 \%$ was also reported but attributed to brick-tea drinking [17] and associated with skeletal abnormalities in the wrist. It was further suggested that the observed dental fluorosis should be seen as a warning sign for the development of skeletal fluorosis. However, no statisti- 


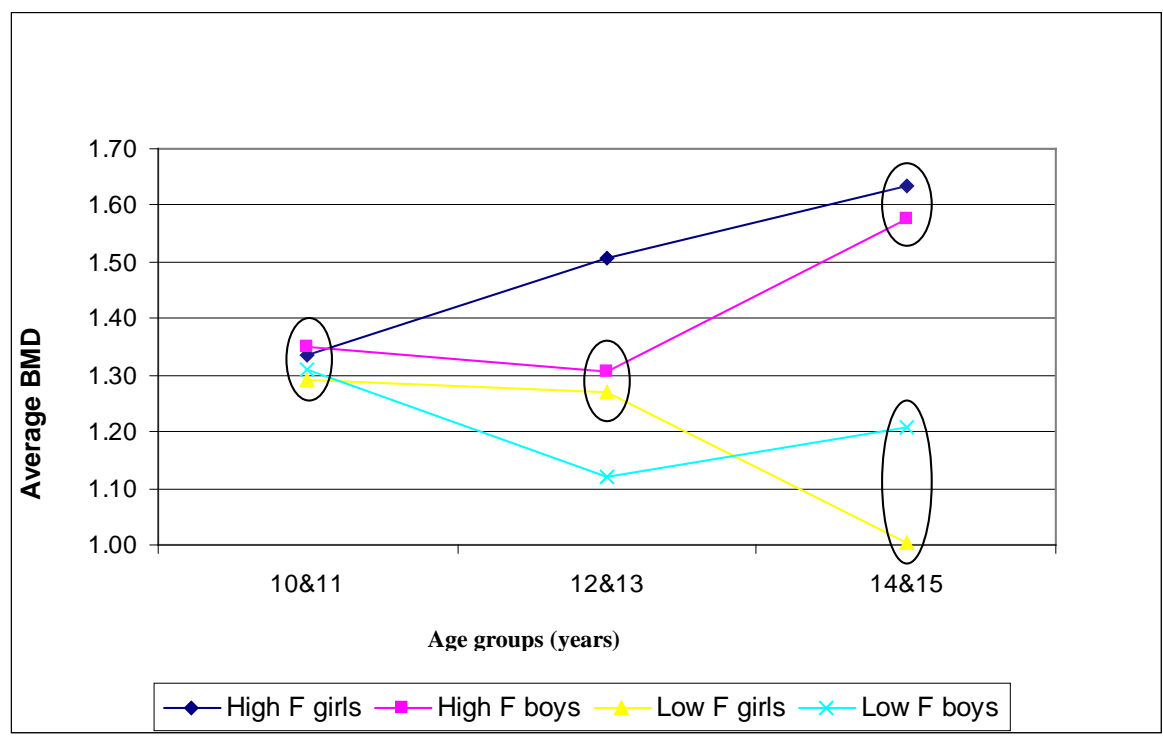

Fig. (3). The average values of the bone mineral density (BMD) over years for the low $(0.19 \mathrm{mg} / \mathrm{L} \mathrm{F})$ and high (3.00 mg/L F) F areas. The values encircled (within each age group) were not significantly different ( $p>0.05$; Tukey Kramer).

cally significant relationships were found between dental fluorosis and $\mathrm{BW}, \mathrm{BMC}$ or BMD in any of the 2 areas, which indicated that even life-long fluoride concentrations which are detrimental towards dental fluorosis (Table 1; mean fluorosis 3.6) had a relatively low influence on bone.

The insignificant differences in the BW (Fig. 1; Table 2) for gender and different fluoride areas indicated no influence of the 2 different water fluoride concentrations on growth. But the increase in bone width with age is normal during the growing phase of children.

The higher BMC in the 12-13 year age group in the high fluoride area can be explained by the fact that bone mass accrual accelerates more or less at these ages as a result of pubertal maturation. This would happen at 11 and 13 years of age, respectively for Western girls and boys [31] when bone mass increases at a high rate for three consecutive years in girls and four years in boys. Although our group can not be considered to fall exactly in the same Western category it provides an idea of growth effects and age.

Bone mineral density is now an acceptable measure for bone mass, the confirmation of osteoporosis and the risk of fragility fractures [15]. Bone mineral density (BMD) correlates well with the probability of fractures in people with osteoporosis as well as with the improvements in BMD following treatment for osteoporosis with a reduced rate of fracture [15]. In our study a higher BMD value was generally associated with more fluoride $(3.00 \mathrm{mg} / \mathrm{L})$ in the drinking water (Fig. 3). However, the bone density difference seems to become more evident at 12-13 years and even more so at 14-15 years of age. Furthermore, in general girls had higher density values than boys in the 12-13 year and 14-15 year age group of the high fluoride area (Fig. 3). Again this could be due to the earlier pubertal growth spurts in girls, with boys lagging behind until their growth spurt at or just before 14-15 years. However, it varied in the different age groups in the low fluoride area (Fig. 3). The bone density decreased significantly $(\mathrm{p}<0.02)$ from the 10 to 15 year age group in the $0.19 \mathrm{mg} / \mathrm{L} \mathrm{F}$ area (Fig. 3). This might be due to the fact that as the children grow, the low amount of fluoride obtained from the drinking water consumed $(\mathrm{F}=0.19 \mathrm{mg} / \mathrm{L})$ was not enough to support an increase in bone density and the bone density started to decrease as a result of fluoride depletion. In contrast, the other higher fluoride $(3 \mathrm{mg} / \mathrm{L} \mathrm{F})$ area might obtain relatively sufficient fluoride from water over the 10-15 year period. The bone density values reported in this study (Table 2) correspond in general to published values $[14,31]$. From Fig. (3), it seems that after the age of 12 years (or after 12 years of fluoride intake) the difference in bone density becomes more evident as the graphs for the 2 different fluoride areas did not intersect.

In a study where the effect of long-term exposure to fluoride in drinking water $(1.0 \mathrm{mg} / \mathrm{L})$ on risks of bone fractures was investigated, a decrease in the risk of overall fractures was reported but not for hip fractures [32]. Furthermore, 33 Australian studies provide substantial evidence that fluoride up to $1 \mathrm{mg} / \mathrm{L}$ did not have an adverse effect on bone strength, bone mineral density or fracture incidence [15]. However, from the five cross-sectional studies it was concluded that usage of fluoridated water at $1 \mathrm{mg} / \mathrm{L}$ had a favorable effect on bone density [15], as was observed in our 3 $\mathrm{mg} / \mathrm{L}$ fluoride area (Fig. 3). On the other hand, In another study where the drinking water had been fluoridated over a period of 30 years to $1 \mathrm{mg} / \mathrm{L}$, no influence on bone density was found but a possibility in the reduction of osteoporotic hip fractures in the very old was reported [14]. A large body of epidemiological evidence exists in studies on different geographical areas and on different populations showing no adverse effect on bone from drinking fluoridated water (1 $\mathrm{mg} / \mathrm{L})$. Indeed the evidence would suggest it might be beneficial $[8,15]$. Many studies indicated that fluoride in water at levels considered "optimal" for the prevention of dental caries ( around $1 \mathrm{mg} / \mathrm{L} \mathrm{F}$ ) increases bone mineral densities [10, 33-35] while others could not see an increase. In a long-term exposure [34], significantly higher bone density was reported in women for a $1.0 \mathrm{mg} / \mathrm{L} \mathrm{F}$ area than for an area with 0.1 $\mathrm{mg} / \mathrm{L}$ which indicated the effect of water fluoridation during the growing years. A high positive correlation was also 
found between the fluoride concentrations in water $(0.32$ $\mathrm{mg} / \mathrm{L}, 1.69 \mathrm{mg} / \mathrm{L}$ and $2.74 \mathrm{mg} / \mathrm{L}$ ) and bone density [33] as well as for women in Taiwan in areas with $<0.6$ and $>1.0$ $\mathrm{mg} / \mathrm{L}$ fluoride [35]. In a study [36] on 15 and 17 years old, it was stated that the bone area explained most of the variance in BMC and BMD. In agreement with our study, it was also found [36] that the BMC was higher in the region with 10 times more fluoride $(1.1 \mathrm{mg} / \mathrm{L} \mathrm{F})$ in the drinking water. A higher BMD was also reported [34] for long-term exposure to fluoridated water $(1.0 \mathrm{mg} / \mathrm{L} \mathrm{F})$ compared to an area with $0.1 \mathrm{mg} / \mathrm{L} \mathrm{F}$ for adulthood women. No differences between the two groups were found for height, weight, lifestyle or dietary factors.

As this study is a study on children in two very remote areas it can be expected to have some limitations. Unfortunately, there were no medical records available from where more information could have been extracted such as the incidence of bone fracture and bone fluorosis scores. Furthermore, the bone measurements could only be made at one point. In this study the Norland single energy photon absorptiometer was used as it is a portable apparatus and used by other researchers $[25,26]$. However, it should be admitted that more sophisticated apparatuses are available but then they are mostly bulky and costly. However, even with this limitation significant trends were observed.

It can be anticipated that a dental fluorosis index (3.6; Table 1) found in the high fluoride area $(3 \mathrm{mg} / \mathrm{L})$ might be associated with the early-stage of skeletal fluorosis. This argument is based on a study [17] where a dental fluorosis index of 3.7 was associated with the early-stage of skeletal fluorosis and the report by the National Research Council [16] that a maximum drinking water fluoride standard of 4 $\mathrm{mg} / \mathrm{L}$ is too high and does not protect against adverse health effects as skeletal fluorosis especially for life-long residents in these areas. Furthermore, this study did not show any relationship between fluorosis and bone mineral density at these $0.19 \mathrm{mg} / \mathrm{L}$ and $3.00 \mathrm{mg} / \mathrm{L}$ fluoride (which is still considered to be low in general medical terms) low drinking water fluoride levels. A strong positive linear relationship was detected between age and bone width of life-long resident children. The bone mineral density increased with age in a high fluoride area $(3 \mathrm{mg} / \mathrm{L})$ but decreased with age in the low fluoride area $(0.19 \mathrm{mg} / \mathrm{L})$.

\section{REFERENCES}

[1] Harrison PTC. Fluoride in water: A UK perspective. J Fluor Chem 2005; 126: 1448-56.

[2] Davies MJ, Spencer AJ. The child dental health survey Australia, 1993. AIHW DSRV, 1995; (Dental Statistics and Research Series No. 7).

[3] Spencer AJ, Davies MJ, Slade GD, Brennan D. Caries prevalence in Australasia. Int Dent J 1994; 44: 415-23.

[4] Spencer AJ, Slade GD, Davies MJ. Water fluoridation in Australia. Com Dent Health 1996; 2: 27-37.

[5] Jones CM, Taylor GO, Whittle JG. Water fluoridation, tooth decay in 5 year olds, and social deprivation measured by the Jarman score. Analysis of data from the British dental surveys. Br Med J 1997; 15: 514-7.

[6] Du Plessis JB. The effect of socio-economic status on dental caries experience in 6,12 and 15 year-old school children in Port Elizabeth and Dispatch. J Dent Assoc S Afr 1979; 54: 483-6.

[7] Grobler SR, Louw AJ, van Wyk Kotze TJ. Dental fluorosis and caries experience in relation to three different drinking water fluoride levels in South Africa. Inter. J Paeditr Dent 2001; 11: 372-9.
[8] Grobler SR, van Wyk Kotze CW, Kotze D. Relationship between enamel fluoride levels, degree of fluorosis and caries experience in communities with a nearly optimal and a high fluoride level in the drinking water. Caries Res 1986; 20: 284-8.

[9] Louw AJ, Grobler SR, van Wyk Kotze TJ. Degree of fluorosis in areas of South Africa with differing levels of fluoride in drinking water. Gen Dent 2002; 13: 352-6.

[10] Manji F, Baelum V, Fejerskov O. Dental fluorosis in an area of Kenia with $2 \mathrm{mg} / \mathrm{L}$ fluoride in the drinking water. J Dent Res 1986; 65: 659-62.

[11] Aziz Ghandour IA, Ibrahim FA, Shehata AH. The prevalence of dental caries, fluorosis, and dental attitudes among primary schoolchildren in Omdurman-Sudan. Odontostomatol Trop 1988; 11: 103-6.

[12] Ng'ang'a PM, Valderhaug J. Prevalence and severity of dental fluorosis in primary schoolchildren in Nairobi, Kenya. Commun Dent Oral Epidemiol 1993; 21: 15-18.

[13] ADA Association. Position of the American Dietetic Association: The impact of fluoride on health. J Am Diet Assoc 2005; 105: 1620-8.

[14] Lehmann R, Wapniarz M, Hofmann B, Pieper B, Haubitz I, Allolio B. Drinking water fluoridation: Bone mineral density and hip fracture incidence. Bone 1998; 22: 273-8.

[15] Demos LL, Kazda H, Cicuttini FM, Sinclair MI, Fairley CK. Water fluoridation, osteoporosis, fractures : recent developments. Aust Dent J 2001; 46: 80-7.

[16] USA National Academy of Sciences, National Research Council. Fluoride in Drinking water. Committee on Fluoride in Drinking Water: Report prepared by the National Research Council. National Academies Press, 500 Fifth Street, NW, Washington, D.C. 20001; Academic press (800) 624-6242, 2006. www.nap.edu

[17] Cao J, Lui J, Tang L, Sangbu D, Yu S, Zhou S, et al. Dental and early-stage skeletal fluorosis in children induced by fluoride in brick-tea. Fluoride 2005; 38: 44-7.

[18] World Health Organization. Oral health surveys: Basic methods, $3^{\text {rd }}$ ed., Geneva: WHO 1987.

[19] Nicholson K, Duff EJ. Fluoride determination in water. Anal Lett 1981; 14A7: 493-517.

[20] Grobler SR, Dreyer AG. Fluoride levels in the drinking water of South Africa and South West Africa. J Dent Assoc S Afr 1984; 39: 793-7.

[21] Grobler SR, Kotze VW, Kotze TJ, Cleymaet R. Fluoride concentration in drinking water in small villages in the Cape province. J Dent Assoc S Afr 1991; 46: 571-4.

[22] Du Plessis JB, Louw AJ, van der Merwe CA. Calibration of examiners for the National Oral Health Survey: Caries and periodontal diseases. Natl Oral Health Survey S Afr 1988; 89: 15-23.

[23] Cohen J. The coefficient of agreement for nominal scales. Educ Physiol Meas 1960; 20: 37-46.

[24] Landis JR, Koch GG. The measurement of observer agreement on categorical data. Biometrics 1977; 33: 159-74.

[25] Cameron JR, Sorenson J. Measurement of bone mineral in vivo. An improved method. Science 1963; 142: 230.

[26] Wahner HW, Riggs BL. Method and application of bone densitometer in clinical diagnosis. CRC Crit Rev Clin Lab Sci 1986; 24 : 217-33.

[27] Grobler SR, Dreyer AG. Variations in the fluoride levels of drinking water in South Africa. S Afr Med J 1988; 73: 217-19.

[28] Mellberg JR, Ripa LW. Fluoride in Preventive Dentistry. Chicago: Quintessence Publishing 1983.

[29] El-Nadeef MAI, Honkala E. Fluorosis in relation to fluoride levels in water in central Nigeria. Commun Dent Oral Epidemiol 1998; 26: $26-30$.

[30] Olsson B. Dental findings in high fluoride areas in Ethiopia. Commun Dent Oral Epidemiol 1979; 7: 51-6.

[31] Carrie-Fassler AL, Bonjour JP. Osteoporosis as a pediatric problem. In: Gaul GE, Ed. Pediatr Clin North Am 1995; 42: 811-24.

[32] Li Y, Liang C, Slemenda CW, et al. Effect of long-term exposure to fluoride in drinking water on risks of bone fractures. J Bone Miner Res 2001; 16: 932-39.

[33] Czarnowski W, Krechniak J, Urbanska B, Stolarska K. The impact of water-borne fluoride on bone density. Fluoride 1999; 32: 91-5.

[34] Arnold CM, Bailey DA, Faulkner RA, McKay HA, McCulloch RG. The effect of water fluoridation on the bone mineral density of young women. Can J Public Health 1997; 88: 388-91. 
[35] Lan CF, Lin IF, Wang SJ. Fluoride in the drinking water and the bone mineral density of women in Taiwan. Int J Epidemiol 1995; 24: 1182-7.
[36] Bratteb LE, Samuelson G, Sandhagen B, et al. Whole-body mineral measurements in Swedish adolescents at 17 years compared to 15 years of age. Acta Paediatr 2002; 91: 1031-8.

(C) Grobler et al.; Licensee Bentham Open.

This is an open access article licensed under the terms of the Creative Commons Attribution Non-Commercial License (http: //creativecommons.org/licenses/ by-nc/3.0/) which permits unrestricted, non-commercial use, distribution and reproduction in any medium, provided the work is properly cited. 